\title{
Respon Awal Petani, Nelayan, dan Usaha Mikro, Terhadap Bantuan COVID-19
}

\author{
(Initial Response of Farmers, Fishers, and Micro-enterprises \\ toward COVID-19 Recovery Funds)
}

\author{
Crisanty Sutristyaningtyas Titik, Ris Yuwono Yudo Nugroho* \\ Fakultas Ekonomi dan Bisnis Universitas Trunojoyo Madura \\ Kabupaten Bangkalan, Jawa Timur, Indonesia \\ E-mail: ris.nugroho@trunojoyo.ac.id
}

\begin{abstract}
Abstrak
Penelitian secara umum bertujuan untuk mengevaluasi pelaksanaan Program Respon Covid-19 berdasarkan persepsi masyarakat penerima manfaat. Pendekatan kualitatif digunakan untuk mengkaji dan menafsirkan makna dari individu atau kelompok orang. Responden dipilih secara purposive di tiga kabupaten di Jawa Timur, yaitu Lamongan, Bangkalan, dan Gresik. Kesimpulan penelitian, bahwa: (1) informasi awal sudah cukup jelas, proses memperoleh bantuan mudah, demikian pula persyaratan yang harus dipenuhi, (2) pelaksanaan bantuan tanggap pandemi telah berjalan, seiring dengan bantuan sosial yang telah berjalan sebelumnya, dan (3) dampak pandemi terhadap pendapatan masyarakat tergantung dari jenis usaha, skala usaha, kemampuan strategi pemilik usaha. Indikasi awal bahwa sektor usaha mikro lebih rentan terkena dampak pandemi.
\end{abstract}

Kata Kunci: Kebijakan Fiskal, Program Kesejahteraan, COVID-19

\begin{abstract}
In general, research proposes to assess the Covid-19 Response Program's implementation based on the receiver community's perceptions. A qualitative approach is used to study and interpret the meaning of an individual or group of people. Respondents were selected purposively in three districts in East Java, namely Lamongan, Bangkalan, and Gresik. The following is a brief conclusion that: (1) initial information is clear enough; thus, the process of obtaining assistance is simple, and the requirements that must be met are also pleased, (2) implementation of pandemic response assistance has been running, and social service has been running before, and (3) impact of the pandemic community income depends on the type of business, its scale, and its strategic capabilities. Initial indications that the micro-business sector is more vulnerable to the impact of the pandemic.
\end{abstract}

Keywords: Fiscal Policies, Welfare Programs, COVID-19

\section{Pendahuluan}

Pandemi COVID 19 yang dilaporkan di Wuhan Desember 2019, telah menyebar lebih dari 200 negara, serta penyebarannya saat ini sudah bersifat lokal di tiap negara (WHO, 2020). Sampai akhir September 2020, kasus positif virus menimpa sekitar 33 juta orang, dengan korban meninggal mencapai satu juta orang di seluruh dunia (www.woldometer.info). Pandemi dengan akar penyebab masalah kesehatan masyarakat tersebut, dampaknya berkembang menjadi goncangan ekonomi yang luas, menimbulkan shock pada aggregate demand dan aggregate supply, serta rantai pasok global pada hampir semua sektor ekonomi (Siregar, 2020).

Bank Indonesia melalui kebijakan moneter, melakukan respon kebijakan untuk menjaga likuiditas. Kebijakan tersebut antara lain Quantitative easing dengan membeli SBN di pasar sekunder; penurunan Giro Wajib Minimum (GWM), serta mendorong percepatan implementasi ekonomi dan keuangan digital melalui kolaborasi antarbank dan fintech kepada UMKM dan masyarakat. Pada sisi

\footnotetext{
${ }^{*}$ Corresponding Author

e-Journal Ekonomi Bisnis dan Akuntansi, 2021, Volume 8 (1): 8-19
}

kebijakan fiskal, pemerintah melakukan respon berupa kebijakan stimulus. Kebijakan stimulus I dengan fokus memperkuat ekonomi domestik, kebijakan stimulus II dengan fokus menjaga daya beli, serta kebijakan stimulus III berupa tambahan belanja pemerintah. Sampai dengan September 2020 bantuan untuk pemulihan ekonomi, dianggarkan sekitar Rp 695 juta.

Dibandingkan krisis keuangan Asia tahun 1997-1998 dan krisis keuangan global tahun 2008, sifat krisis COVID-19 justru langsung menimpa sektor rumah tangga dan usaha kecil menengah. Pandemi ini juga berpotensi membawa dampak sosial yaitu terhadap kemiskinan dan pengangguran. Jumlah orang dengan kategori miskin diprediksi akan bertambah 1,16 juta orang dengan skenario berat, dan bertambah 3,78 juta orang dengan skenario sangat berat. Jumlah penganguran diprediksi bertambah 2,92 juta orang dengan skenario berat, dan bertambah 5,23 juta orang dengan skenario sangat berat dianggarkan sekitar Rp 695 juta.

Berdasarkan data Sakernas 2019 Semester II, kondisi ketenagakerjaan menunjukkan 52 persen pekerja, bekerja

ISSN : 2355-4665 
pada sektor yang rentan terdampak COVID 19 yaitu sektor Industri, Perdagangan, dan Akomodasi Makanan Minuman (BPS, 2019). Gambaran lebih detail dari sisi kontrak kerja, menunjukkan bahwa 44 persen pekerja tersebut, tidak memiliki kontrak kerja dngan tempat dia bekerja, sehingga rawan terhadap PHK. Ditinjau dari rumah tangga usaha pertanian dalam kurun waktu 10 tahun (2003-2013) mengalami penurunan sekitar 16,32 persen secara absolut berkurang sekitar 5,10 juta rumah tangga.

Pemerintah berupaya menekan dampak COVID-19 kepada masyarakat luas, khususnya masyarakat berpendapatan rendah. Beberapa insentif bantuan sosial sudah dan akan dikucurkan pemerintah. Pertama, Program Keluarga Harapan (PKH) untuk 10 Juta Keluarga Penerima Manfaat (KPM); kedua, Program Kartu Sembako untuk 20 Juta penerima; ketiga, Program Kartu Prakerja untuk 5,6 juta Peserta, keempat, diskon tarif bagi Pelanggan 450 VA dan 900 VA Subsidi, dan terakhir, Stimulus Kredit Usaha Rakyat, yang bertujuan untuk meringankan beban UMKM (Kemenkeu, 2020).

Beberapa regulasi dan peraturan telah dikeluarkan pemerintah untuk mengatasi COVID-19 secara luas (Joharudin et al, 2020), meskipun banyak yang tidak harmonis dan menimbulkan problematika baru di tengah masyarakat yang panik akibat wabah (Mufida, 2020). Buana (2020) dengan pendekatan psikologi menunjukkan banyaknya masyarakat Indonesia yang tidak mematuhi himbauan dari pemerintah untuk menanggulangi pandemi virus corona. Djalante et al. (2020) menekankan selain masalah kesehatan, ketahanan masyarakat secara ekonomi, infrastruktur fisik serta sosial juga harus mendapat perhatian.

Fakhruddin et al. (2020) menunjukkan bahwa isu pemulihan ekonomi akan menjadi topik berikutnya pasca pendemi, dan respon terhadap pandemi berupa perbaikan data dan respon masyarakat sangat diperlukan. Pakpahan (2020) menyatakan bahwa kebijakan jangka pendek terhadap UMKM untuk penanganan COVID-19 adalah dengan bantuan keuangan baik dalam bentuk pinjaman lunak atau bantuan tunai langsung dengan melibatkan pemerintah dan sektor swasta. Penelitian Khomaini (2020) menunjukkan bahwa program bantuan tunai tidak berdampak pada peningkatan kesejahteraan subjektif rumah tangga penerima, berbeda dengan temuan Kilburn et al. (2016). Sangat menarik untuk mengetahui pelaksanaan upaya pemerintah tersebut di lapangan, penilaian masyarakat terhadap kebijakan yang sedang dijalankan, serta dampak yang dirasakan masyarakat penerima bantuan sosial pada saat pandemic

Penelitan secara deskriptif kualitatif, berupa kajian cepat dari pelaksanaan program bantuan tanggap COVID-19, yang diluncurkan pemerintah untuk membantu masyarakat miskin dan usaha mikro yang terkena dampak pendemi. Pertanyaan khusus dalam penelitian yang menjadi rumusan masalah adalah: (1) bagaimanakah informasi awal pemberian bantuan COVID-19 pada kelompok masyarakat (Petani, Nelayan, dan Usaha Mikro)? (2) bagaimanakah proses pelaksanaan pemberian bantuan? serta (3) bagaimanakah dampak bantuan COVID-19 terhadap masyarakat penerimanya?
Penelitian secara umum bertujuan untuk evaluasi awal pelaksanaan program tanggap COVID-19 berdasarkan persepsi dari sisi masyarakat penerima bantuan tersebut. Secara khusus tujuan penelitian adalah: (1) menganalisis informasi awal pemberian bantuan COVID-19 pada kelompok masyarakat tertentu (Petani, Nelayan, dan Usaha Mikro), (2) mengetahui proses pelaksanaan pemberian bantuan COVID-19, serta (3) menganalisis dampak bantuan COVID-19 dan harapan masyarakat penerimanya.

\section{Kajian Teori}

Peningkatan pendapatan masyarakat terdampak COVID19 melalui pemberian BLT (cash transfer) dapat dijelaskan dengan perilaku konsumen melalui indifference curve (Kurniawati, 2017). Konsumsi kebutuhan pokok pada garis anggaran sebesar B0 dengan utilitas u. Pada saat terjadi pandemi, pendapatan riil masyarakat berkurang dan garis anggaran bergeser menjadi P-F. Pada garis anggaran ini, konsumsi barang kebutuhan pokok juga berkurang menjadi B1 dan utilitasnya menjadi u1. Pemerintah kemudian memberikan cash transfer sebagai mitigasi dampak pandemi (Gambar 2.1).Bagian ini menjelaskan mengenai teori yang relevan dari penelitian terdahulu terkait dengan topik yang dibahas.

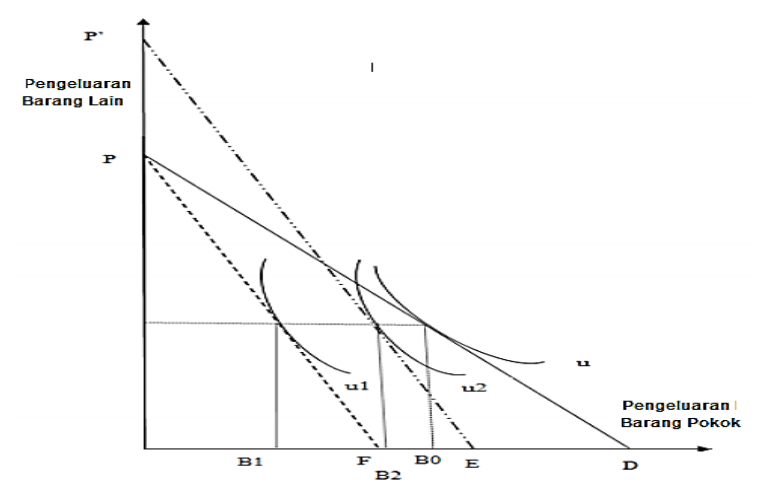

Gambar 1. Kurva Indifference adanya Bantuan Tunai

Tersedianya cash transfer tersebut, maka pendapatan rumah tangga bertambah dan garis anggaran bergeser menjadi P'-E. Pada garis anggaran tersebut, konsumsi barang kebutuhan pokok bertambah menjadi B2 dan utilitas bergeser menjadi u2. Pergeseran garis anggaran akibat adanya cash transfer memungkinkan rumah tangga mempertahankan atau meningkatkan belanja agar tingkat kesejahteraan rumah tangga bertambah. Hal tersebut tidak berlaku, apabila dana kompensasi diberikan dalam bentuk barang. Pemberian kompensasi dalam bentuk barang hanya dapat meningkatkan konsumsi rumah tangga terhadap barang tersebut, namun tidak dapat menggeser garis anggaran.

\section{Dampak COVID 19 terhadap Kesejahteraan Rumah Tangga}

Menurut World Bank (2020) terdapat 4 jalur guncangan agregat aktivitas perekonomian yang mempengaruhi kesejahteraan rumah tangga dan individu, yaitu:

1. Dampak terhadap pendapatan tenaga kerja yang meliputi efek langsung dan tidak langsung. Efek langsung karena sakit atau kebutuhan untuk merawat anggota rumah tangga yang sakit. Efek tidak langsung, 
disebabkan penurunan permintaan agregat dan gangguan pasokan: (a) penurunan jumlah pekerjaan, baik jam atau pekerjaan (b) penurunan upah, yang tidak mungkin bagi pekerja bergaji dalam jangka pendek, tetapi dapat terjadi dari waktu ke waktu karena cuti atau pemotongan upah oleh beberapa pengusaha untuk menghindari PHK; (c) penurunan pendapatan wiraswasta, karena pengurangan kegiatan ekonomi usaha mikro dan kecil, atau karena pembatasan mobilitas, terutama yang terlibat dalam pertanian musiman.

2. Dampak terhadap pendapatan non-tenaga kerja yang meliputi: (a) penurunan pengiriman uang internasional (dan domestik) yang dihasilkan dari dampak ekonomi dari krisis di tempat di mana para migran bekerja serta (b) potensi perubahan dalam transfer publik yang akan meningkat ketika pemerintah merespons untuk mengurangi dampak guncangan, atau penurunan ketika kendala fiskal memaksa negara untuk memilih antara perlindungan sosial dan perawatan kesehatan yang ada.

3. Dampak langsung pada konsumsi melalui: (a) perubahan harga, kekurangan kebutuhan pokok, gangguan dalam fungsi pasar karena penurunan perdagangan, atau penurunan produksi dalam negeri. Efek ini merupakan tambahan terhadap dampak kesejahteraan tidak langsung dari setiap kenaikan harga input produksi, yang akan mempengaruhi biaya produksi dan pendapatan tenaga kerja. (b) Meningkatnya biaya perawatan kesehatan bagi yang terkena dampak langsung pandemi, dapat mengurangi konsumsi kebutuhan lain di antara rumah tangga yang dibatasi kredit.

4. Terjadi gangguan pelayanan, dengan dampak negatif pada dimensi kesejahteraan non-moneter, yaitu: (a) penangguhan kelas dan program pemberian makan di sekolah, yang berdampak pada retensi siswa, pembelajaran, dan gizi, (b) potensi saturasi sistem kesehatan di negara-negara dengan insiden COVID-19 yang tinggi, yang menyebabkan perawatan yang tidak memadai untuk penyakit tidak menular, dan (c) gangguan mobilitas dikarenakan karantina dan tindakan penahanan lainnya yang dapat secara drastis mengurangi layanan transportasi umum dan pribadi

\section{Kebijakan Pemerintah Merespon Pandemi}

Kebijakan pemerintah menghadapi dampak COVID-19 dapat diakses di laman resmi kementrian keuangan pada bagian tanggap COVID-19 (https://www.kemenkeu.go.id/COVID19). Laman tersebut antara lain menyatakan bahwa anggaran negara diprioritaskan untuk (a) menjamin kesehatan dan keselamatan masyarakat, termasuk tenaga medis; (b) memastikan perlindungan dan Jaring Pengaman Sosial untuk masyarakat rentan; dan (c) perlindungan terhadap dunia usaha. Total biaya penanganan dampak COVID-19 dialokasikan sebesar Rp 677,20 triliun, terdiri atas: (a) bidang kesehatan Rp87,55 triliun; dan (b) pemulihan ekonomi nasional: Rp 589,65 T, yang terdisi atas demand side: Rp205,2 T, dan supply side Rp384,45 T.
Pemerintah menggunakan APBN untuk membantu masyarakat yang penghasilannya berkurang atau hilang, dan memastikan ketersediaan bahan kebutuhan pokok. Kebijakan untuk rakyat miskin, antara lain:

1. Penyaluran PKH yang sebelumnya per 3 bulan, menjadi per bulan mulai April hingga Desember 2020. Bulan April s.d Juni, KPM menerima PKH 2 kali (triwulanan indeks lama dan bulanan indeks baru).

2. Besaran manfaat PKH per tahun untuk: (1) Ibu hamil Rp3.750.000; (2) Anak usia 0-6 tahun Rp 3.750.000; (3) Anak SD/sederajat Rp1.125.000; (4) Anak SMP/sederajat Rp1.875.000; (5) Anak SMA/sederajat Rp2.500.000; (6) Disabilitas berat Rp3.000.000; (7) Lansia 70 tahun ke atas Rp3.000.000. Bantuan PKH diberikan maksimal kepada 4 orang dalam 1 keluarga. Bantuan tertinggi Rp10 juta/tahun, bantuan terendah Rp900 ribu/tahun.

3. Nominal Kartu Sembako naik dari Rp150.000 menjadi Rp200.000 per KPM, diberikan selama sembilan bulan hingga Desember 2020.

4. Bantuan Langsung Tunai (BLT) Desa sebesar Rp600 ribu/KPM/bulan (April-Juni 2020) dan Rp300 ribu/KPM/bulan (Juli-September 2020). BLT Desa diberikan kepada keluarga miskin atau tidak mampu di desa yang bukan penerima bantuan PKH, Kartu Sembako, dan Kartu Pra Kerja. Pendataan calon KPM mempertimbangkan Data Terpadu Kesejahteraan Sosial (DTKS) Kementerian Sosial.

5. Bansos tunai non-Jabodetabek untuk 9 juta KPM di luar Jabodetabek yang tidak menerima PKH dan Kartu Sembako. Nilai manfaat sebesar Rp600 ribu/KPM/bulan (April-Juni 2020) dan Rp300 ribu/KPM/bulan (Juli-Desember 2020) dalam bentuk tunai.

6. Pembebasan biaya listrik pasca bayar dan prabayar selama 6 bulan (April-September 2020) untuk 24 juta pelanggan listrik $450 \mathrm{VA}$, dan diskon $50 \%$ untuk 7,2 juta pelanggan $900 \mathrm{VA}$.

Sedangkan untuk sektor Usaha Mikro, Kecil, dan Menengah, kebijakan pemerintah bersama BI dan OJK antara lain:

1. PPh final $0,5 \%$ (PP 23/2018) ditanggung pemerintah untuk pelaku UMKM. Wajib pajak UMKM tidak perlu melakukan setoran pajak dan pemotong pajak tidak melakukan pemotongan pajak pada saat melakukan pembayaran kepada pelaku UMKM.

2. Subsidi bunga/subsidi margin diberikan kepada debitur usaha mikro, usaha kecil, dan usaha menengah, dengan plafon kredit/pembiayaan paling tinggi Rp10 miliar, dalam jangka waktu paling lama 6 bulan. Mulai berlaku sejak tanggal 1 Mei 2020.

3. Kriteria penerima subsidi bunga/subsidi margin: (1) memiliki baki debet kredit/pembiayaan s.d. 29 Februari 2020; (2) tidak termasuk dalam Daftar Hitam Nasional; (3) memiliki kategori performing loan lancar (kolektibilitas 1 atau 2) dihitung per tanggal 29 Februari 2020; dan (4) memiliki NPWP atau mendaftar untuk mendapatkan NPWP.

4. Debitur dengan plafon kredit/pembiayaan kumulatif di atas Rp500 juta s.d. Rp10 miliar harus memperoleh restrukturisasi dari penyalur kredit/pembiayaan. 
5. Bagi debitur yang memiliki beberapa akad kredit/pembiayaan kumulatif Rp500 juta s.d. Rp10 miliar, subsidi bunga/subsidi margin diberikan untuk paling banyak 1 akad kredit/pembiayaan.

6. Besaran subsidi bunga/subsidi margin untuk debitur dari lembaga penyalur program kredit pemerintah dengan plafon kredit/pembiayaan: (1) s.d. Rp10 juta paling tinggi 25\% selama 6 bulan; (2) Rp10 juta s.d. Rp500 juta sebesar 6\% selama 3 bulan pertama dan 3\% selama 3 bulan berikutnya; dan (3) Rp500 juta s.d. Rp10 miliar sebesar 3\% selama 3 bulan pertama dan $2 \%$ selama 3 bulan berikutnya.

7. Besaran subsidi bunga/subsidi margin untuk debitur dari perbankan atau perusahaan pembiayaan dengan plafon kredit/pembiayaan: (1) s.d. Rp500 juta sebesar $6 \%$ selama 3 bulan pertama dan $3 \%$ selama 3 bulan berikutnya; dan (2) lebih dari Rp 500 juta s.d. Rp 10 miliar sebesar $3 \%$ selama 3 bulan pertama dan $2 \%$ selama 3 bulan berikutnya.

8. Restrukturisasi KUR berupa perpanjangan jangka waktu KUR, penambahan limit plafon KUR, dan/atau penundaan pemenuhan persyaratan administratif dalam proses restrukturisasi sampai dengan berakhirnya masa darurat COVID-19.

9. Anggaran Kartu Prakerja dinaikkan Rp10 triliun menjadi Rp20 triliun untuk 5,6 juta pekerja yang terkena PHK atau dirumahkan, pekerja informal, dan pelaku usaha mikro dan kecil yang terdampak COVID-19. Penerima manfaat menerima biaya pelatihan Rp1 juta, insentif pasca pelatihan Rp600 ribu/bulan selama 4 bulan, dan insentif survei kebekerjaan Rp150 ribu untuk 3 kali survei.

\section{Penelitian Pendukung}

Rosfadhila et al (2011) meneliti tentang pelaksanaan program Bantuan Langsung Tunai tahun 2008 dan Evaluasi Penerima Program BLT 2005 di Indonesia. Hasil temuannya bahwa program BLT masih relevan membantu masyarakat miskin mengatasi guncangan akibat kenaikan harga BBM. Meskipun masyarakat miskin merasa terbantu, sebagian aparat pelaksana program keberatan atas perlanjutan program dan menyarankan supaya program diganti dengan program pemberdayaan masyarakat, serta masih terjadi kesalahan penetapan sasaran penerima karena verifikasi tidak berjalan dengan baik. Khomaini (2020) mengkaji dampak program bantuan tunai (cash transfer) terhadap kesejahteraan di Indonesia. Hasil riset bahwa program tersebut di Indonesia berkorelasi negatif atau tidak berdampak pada peningkatan kesejahteraan rumah tangga penerima dibandingkan dengan non-penerima manfaat, berbeda dengan temuan Kilburn et al. (2016) untuk kasus di Malawi.

Beberapa penelitian berikut mengkaji respon masyarakat terhadap peraturan pemerintah atau respon terhadap program bantuan tertentu. Penelitian Jonyanis dan Wahyuni (2015), serta Fadli (2017), meneliti respon nelayan terhadap program bantuan pemerintah dan peraturan menteri. Riset dari Putra dan Haryati (2018) membahsa tentang respon para peetani terhadap padi varietas baru, sedangkan Budianto (2015) menganalisis respon anggota kelompok tani terhadap Program Pengembangan Usaha Agribisnis Perdesaan. Penelitian
Hidayat (2018) meneliti respon pelaku usaha terhadap kewajiban sertifikasi halal, sedangkan Purwono, Nugroho, dan Mubin (2019) meneliti respon pelaku UMKM terhadap pelaksanaan KUR dengan skema baru.

\section{Metode}

\section{Pendekatan dan Definisi}

Penelitian menggunakan pendekatan kualitatif untuk mengekplorasi dan memahami makna sejumlah individu atau sekelompok orang dari masalah sosial. Proses dilakukan dengan melibatkan upaya seperti mengajukan pertanyaan dan prosedur, pengumpulan data dari responden, menganalisis data, serta menafsirkan data tersebut (Creswell dan Creswell, 2017). Neuman (2017) menyatakan bahwa pendekatan kualitatif antara lain berfokus pada proses dan peristiwa interaksi, menilai saat ini, dan tergantung situasi, serta keotentikan menjadi faktor utama. Fenomena yang ingin diungkap adalah pelaksanaan program tanggap COVID-19 berdasarkan persepsi dari sisi masyarakat penerima bantuan tersebut. Secara khusus penelitian untuk memahami informasi awal pelaksanaan bantuan tanggap COVID-19, pelaksanaan bagaimana masyarakat memperoleh bantuan tanggap COVID-19, serta dampak bantuan COVID-19 terhadap pendapatan masyarakat penerimanya.

Respon berasal dari kata response, yang berarti jawaban, balasan, atau tanggapan (reaction). Kamus Besar Bahasa Indonesia menjelaskan pengertian respon sebagai tanggapan, reaksi, dan jawaban. Respon diartikan suatu tingkah laku atau sikap yang berwujud baik sebelum pemahaman yang mendetail, penilaian, pengaruh atau penolakan, suka atau tidak serta pemanfaatan pada suatu fenomena tertentu. Respon awal menyangkut periode pemberian bantuan COVID-19 yang sedang berlangsung, sehingga beberapa bantuan yang diterima responden, mungkin merupakan program yang sudah berlangsung atau program transisi. Pelaksanaan meliputi informasi, persyaratan, mekanisme, dan prosedur memperoleh bantuan. Penilaian meliputi kejelasan informasi, kemudahan proses, dan ketepatan sasaran pemberian bantuan. Dampak merupakan akibat adanya bantuan sosial terhadap pendapatan dan pengeluaran usaha, atau rumah tangga.

Usaha mikro mengacu pada definisi industri mikro menurut BPS, yaitu adalah perusahaan industri (entitas usaha) yang tenaga kerjanya antara 1-4 orang. Petani yang dimaksud disini adalah orang yang mengusahakan usaha pertanian (tanaman bahan makanan dan tanaman perkebunan rakyat) atas resiko sendiri dengan tujuan untuk dijual, baik sebagai petani pemilik maupun petani penggarap (sewa/kontrak/bagi hasil). Termasuk dalam survei ini adalah orang yang bekerja di sawah/ladang orang lain dengan mengharapkan upah (buruh tani). Nelayan adalah orang yang secara aktif melakukan pekerjaan dalam operasi penangkapan ikan/binatang air lainnya/tanaman air. Bantuan tanggap COVID-19 mengacu kebijakan bantuan untuk UMKM dan untuk rakyat miskin seperti tercantum pada website kementrian keuangan. 


\section{Pengumpulan Informasi}

Proses dan prosedur pengumpulan informasi:

1. Memilih secara purposive lokasi dan individu sesuai dengan tujuan penelitian. Lokasi penelitian berdasarkan tujuan penelitian yaitu pelaku usaha mikro, petani dan nelayan. Propinsi Jawa Timur menjadi lokasi penelitian, dan dipilih 3 kabupaten yang berbeda untuk memahami fenomena tiap kategori, dengan menggunakan 3 responden di tiap 3 kabupaten (Tabel 1).

Tabel 1. Sebaran Responden

\begin{tabular}{cllcc}
\hline No. & Kategori & Kabupaten & $\begin{array}{c}\text { Jumlah } \\
\text { Responden }\end{array}$ & $\begin{array}{c}\text { Pelaksanaan } \\
\text { Wawancara }\end{array}$ \\
\hline 1 & Petani & Lamongan & 3 & Agustus- \\
2 & Nelayan & Bangkalan & 3 & September \\
3 & Usaha & Gresik & 3 & 2020 \\
& Mikro & & & \\
\hline
\end{tabular}

Sumber: data primer, 2020

2. Untuk mempertajam analisis, kategori responden dengan mengakomodir untuk petani dan nelayan dengan mengakomodir petani dan nelayan gurem, dan untuk UMKM dari sub sektor ekonomi kreatif.

3. Jenis data yang dikumpulkan berasal (a) observasi mengamati perilaku responden, (b) wawancara yang bersifat terbuka maupan terstruktur untuk memunculkan pandangan dan opini dari responden, dan (c) dokumen-dokumen kualitatif dan hasil rekaman audio atau visual.

4. Analisis Informasi

Beberapa langkah untuk melakukan analisis informasi dengan pendekatan kualitatif: (1) mengolah dan mempersiapkan data, melakukan transkripsi wawancara, menyusun berbagai jenis sumber data (2) membaca keseluruhan data, mengambil gagasan umum yang terkandung dalam pernyataan responden, (3) menganalisis lebih detail menjadi segmen-segmen tulisan sebelum memaknai, (4) melakukan penggolongan deskripsi berdasarkan tujuan penelitian, (5) penyajian dalam bentuk narasi dan laporan kualitatif.

\section{Hasil dan Pembahasan}

\section{Hasil \\ Responden Petani}

Lokasi penelitian untuk responden petani di Jawa Timur, dipilih secara purposive di Kabupaten Lamongan, tepatnya di Desa Gondang Lor Kecamatan Sugio. Kabupaten Lamongan merupakan kabupaten dengan luas panen dan produksi padi terbesar di Jawa Timur. Tercatat tahun 2018, luas panen sebesar 151.884 hektar, lebih luas dari Bojonegoro dan Jember pada urutan berikutnya. Kecamatan Sugio merupakan kecamatan dengan luas panen padi terbesar di Kabupaten Lamongan, sehingga dari produksi gabah dan produksi beras, juga merupakan yang terbanyak di Kabupaten Lamongan.

Responden terpilih adalah seorang bapak dan dua orang ibu rumah tangga. Responden pertama berumur 53 tahun, lulusan SD, sebagai kepala rumah tangga dengan 2 orang anggota keluarga lainnya. Responden kedua adalah seorang ibu rumah tangga berumur 49 tahun, tidak lulus SMP, dengan jumlah anggota keluarga seluruhnya 4 orang. Responden ketiga adalah seorang ibu, berumur 61 tahun, dengan pendidikan tidak tamat SD, dan serumah dengan 3 anggota keluarga. Ketiga responden menyatakan kalau responden dan anggota rumah tangga tersebut, belum pernah menerima kredit usaha apapun, baik dari perbankan, pegadaian, maupun perorangan. Salah satu responden menyatakan bahwa tidak berani mengambil kredit usaha karena tidak memiliki penghasilan bulanan yang cukup untuk mencicil

Tingkat pengetahuan tentang wabah COVID, para responden memahaminya sebagai penyakit yang mudah menular sehingga mereka tidak boleh berkumpul atau bergerombol. Meskipun demikian, mereka menyatakan masih tetap keluar rumah seperti biasa untuk pergi ke sawah karna memang pekerjaan mereka demikian. Tingkat kekhawatiran terhadap kesehatan mereka sendiri, anggota keluarga maupun ketika keluar rumah masih pada tingkat seperti biasa, bahkan ada seorang responden yang menyatakan tidak khawatir sama sekali. Mengenai reaksi masyarakat di sekitar menyikapi kondisi wabah COVID19, ketiganya berpendapat sama, bahwa masyarakat di wilayah tersebut masih kurang mempedulikan penggunaan masker, termasuk dalam melakukan kegiatan sehari-hari seperti ke sawah, bertamu, bahkan ke pasar. Meskipun demikian responden juga merasakan bahwa dalam beraktivitas warga lebih menjaga jarak satu dengan yang lain.

\section{Informasi Awal}

Menurut responden pertama, informasi awal yang diberikan oleh perangkat dusun setempat, mengenai bantuan yang akan terima sudah sangat jelas, bahkan perangkat tersebut bersedia mendatangi ke setiap penerima bantuan untuk proses pendataan. Proses yang perlu dijalankan juga sangat mudah karena telah dibantu pengurusannya oleh aparat dusun. Persyaratan yang diperlukan juga sangat mudah karena hanya memerlukan fotocopy KTP dan KK saja. Mengenai pendapat apakah para penerima bantuan sudah tepat sasaran, sebagian besar menurut responden pertama sudah tepat sasaran, namun terdapat sebagian kecil kasus keluarga yang membutuhkan namun masih tidak menerima bantuan tersebut. Responden mencontohkan terdapat keluarga yang dulunya menerima bantuan atas nama ibunya, namun setelah ibunya meninggal bantuan tersebut berhenti atau dicabut padahal kondisi perekonomian keluarga tersebut menurut responden masih tergolong rendah.

Responden kedua menyatakan bahwa, informasi awal yang diberikan oleh perangkat dusun setempat, mengenai bantuan yang akan terima sudah cukup jelas. Proses yang dilalui dalam pengurusan tidak mengalami kendala, namun pada tiga bulan terakhir, bantuan atas nama beliau tidak keluar padahal masyarakat lain yang sama-sama penerima bantuan tersebut sudah memperoleh sembako. Persyaratan yang diperlukan sangat mudah karena hanya memerlukan fotocopy KTP dan KK dan dibantu pengurusannya oleh perangkat dusun. Ketepatan sasaran program menurut responden, sebagian besar sudah tepat sasaran, namun terdapat sebagian kecil kasus dimana terdapat keluarga yang menurutnya membutuhkan, namun masih belum menerina bantuan. 
Responden ketiga menyatakan bahwa, informasi awal yang diberikan oleh perangkat dusun setempat, mengenai bantuan yang akan terima sudah cukup jelas. Menurut responden tidak banyak proses yang dilalui, karena semua telah diurus oleh petugas. Persyaratan juga sangat mudah karena hanya diwawancarai saja oleh petugas. Ketepatan sasaran program menurut responden, sudah tepat sasaran.

\section{Proses Pelaksanaan}

Responden pertama, menerima bantuan berupa kartu sembako dan diskon tarif pelanggan PLN $450 \mathrm{~V}$. Untuk kartu sembako informasi tentang kartu sembako berasal dari aparat desa, yaitu ketua RT setempat. Menurut responden pertama, proses memperoleh bantuan tersebut sebagai berikut:

1. Perangkat dusun menyeleksi calon penerima bantuan sembako;

2. Ketua RT meminta fotocopy KTP dan KK kepada calon penerima bantuan untuk didaftarkan kepada aparat dusun;

3. Diberikan kartu sembako yg dapat digunakan untuk mengambil bantuan;

4. Setiap bulannya responden mengambil sembako menggunakan kartu tersebut

Bantuan yang pernah diperoleh berupa beras $15 \mathrm{~kg}$, telur 1 $\mathrm{kg}$, buah-buahan seperti apel, jeruk, serta hasil pertanian lainnya seperti bawang merah, kacang tanah, kacang hijau, dan lain-lain. Responden tidak mengetahui secara pasti kapan bantuan tersebut akan berakhir, namun pada kartu sembako tertulis masa berlaku sampai tahun 2023.

Untuk diskon pelanggan PLN $450 \mathrm{~V}$, responden mengetahui informasi tersebut dari petugas tempat pembayaran listrik di Dusun Ngingkrang. Proses memperoleh bantuannya adalah juga melalui ketua RT yang melakukan pendataan calon penerima bantuan dengan meminta fotocopy KTP dan KK, dan pada bulan Mei 2020 bantuan sudah didapatkan dengan tidak adanya tagihan listrik kepada responden. Responden juga kurang mengetahui sampai kapan masa pemberian bantuan tersebut berakhir.

Responden kedua, saat dilakukan wawancara menerima bantuan berupa Program Keluarga Harapan (PKH), kartu sembako, serta diskon tarif pelanggan PLN $450 \mathrm{~V}$. Informasi adanya bantuan tersebut dari perangkat desa, terutama dari ketua RT setempat. Proses yang dilalui untuk menerima bantuan PKH adalah sebagai berikut:

1. Perangkat dusun menyeleksi calon penerima bantuan $\mathrm{PKH}$;

2. Ketua RT meminta kelengkapan, berupa fotocopy KTP dan KK kepada calon penerima bantuan untuk didaftarkan kepada aparat desa;

3. Mendaftarkan ATM untuk pengambilan bantuan nantinya.

Bantuan PKH diterima keluarga tersebut sejak April 2020, yang cara penerimaannya setiap 3 bulan sekali, yaitu untuk tunjangan 2 anak sebanyak Rp. 1.200.000. Selain itu setiap bulan memperoleh bantuan sebesar Rp. 400.000 sampai Rp. 450.000. Responden tidak mengetahui secara pasti kapan bantuan tersebut akan berakhir. Sedangkan pemberi informasi dan prosedur untuk kartu sembako dan diskon diskon tarif pelanggan PLN $450 \mathrm{~V}$, sama persis dengan keterangan responden pertama. Hal tersebut dapat terjadi karena responden pertama dan kedua merupakan anggota warga RT yang sama.

Responden ketiga, saat dilakukan wawancara menerima bantuan berupa kartu sembako, dan diskon tarif pelanggan PLN $450 \mathrm{~V}$. Informasi adanya bantuan tersebut dari perangkat desa setempat, bukan dari RT/RW. Proses yang dilalui untuk menerima bantuan tersebut, awalnya petugas tersebut datang dan melakukan wawancara tentang pendapatan dan pengeluaran. Beberapa hari kemudian responden sudah mendapatkan kartu sembako sebagai alat pengambilan bantuan sembako. Bantuan yang diperoleh berupa Beras $15 \mathrm{~kg}$, telur $1 \mathrm{~kg}$, buah buahan, dan hasil pertanian lainnya seperti bawang merah dan kacang hijau.

Untuk diskon pelanggan PLN 450V, responden merasa tidak terdapat proses pendaftaran. Pada saat responden akan membayar listrik, tagihan untuk responden tidak ada dan diberi tahu oleh petugas bahwa telah mendapatkan potongan pembayaran tagihan listrik dari pemerintah. Pembebasan tagihan pembayaran listrik tersebut, mulai diterima sejak Mei 2020. Responden juga tidak mengetahui sampai kapan masa pemberian bantuan tersebut berakhir.

3. Dampak

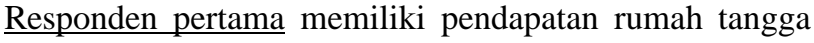
perbulan, dalam kelompok kurang dari 1,8 juta Rupiah. Responden menyatakan bahwa dampak wabah COVID-19 terhadap pendapatan rumah tangga dapat dikatakan tetap. Hal tersebut tercermin dari hasil panen sebelum wabah dan saat wawancara dilakukan, hasilnya relatif tetap. Menurut responden, yang mempengaruhi hasil panen justru karena hama tikus yang menyerang tanaman pada beberapa periode panen terakhir. Demikian pula dengan pengeluaran atau belanja rumah tangga, juga tidak mengalami perubahan.

Bantuan yang diterima saat wawancara, menurut responden sangat meringankan beban ekonomi rumah tangga. Harapan dari responden pertama adalah bantuan terhadap masyarakat miskin dapat diperbanyak, karena pendapatan seorang petani tidak menentu setiap bulannya dan hanya mengandalkan dari hasil panen saja. Saat ini hasil panen sedang terganggu karena adanya serangan hama tikus. Responden juga berharap adanya bantuan dari pemerintah untuk pemberantas hama seperti pestisida maupun obat tikus. Upaya yang dilakukan agar usaha pertaniannya tidak memburuk, dengan mengutamakan pemberantasan hama tikus yang dalam beberapa tahun terakhir merusak tanaman dan dapat mengurangi hasil panen petani. Upaya yang dilakukan untuk memperbaiki ekonomi keluarga agar tidak memburuk adalah dengan tetap bekerja keras.

Responden kedua, juga memiliki pendapatan rumah tangga perbulan yang masuk ke dalam kelompok kurang dari 1,8 juta Rupiah. Responden merasakan bahwa wabah COVID-19 menurunkan pendapatan rumah tangga, meskipun dari hasil panen tidak signifikan mempengaruhi. Justru yang mempengaruhi adalah banyaknya hama tikus yang meyerang saat area persawahan. Sama dengan responden pertama, responden kedua merasakan tidak mengalami perubahandalam pengeluaran atau belanja rumah tangga. 
Bantuan yang diterima saat ini, menurut responden sangat membantu beban ekonomi rumah tangga. Sama dengan responden pertama, harapannya bantuan terhadap masyarakat dapat diperbanyak. Responden juga berharap adanya bantuan pemerintah untuk memberantas hama tikus. Upaya yang dilakukan agar usaha pertaniannya tidak memburuk, dengan lebih mengutamakan pemberantasan hama tikus yang merusak tanaman dan mengurangi hasil panen. Upaya tersebut juga diyakini responden dapat mengatasi ekonomi keluarga agar tidak memburuk.

Responden ketiga, memiliki pendapatan rumah tangga perbulan yang juga masuk ke dalam kelompok kurang dari 1,8 juta Rupiah. Responden merasakan bahwa penurunan pendapatan rumah tangga, yang berasal dari penurunan hasil panen, bukan merupakan dampak dari wabah COVID-19 tetapi karena hama tikus, ulat dan burung yang saat ini sedang menyerang tanaman pada beberapa periode panen terakhir. Justru menurut responden wabah COVID memberikan dampak terhadap hasil penjualan pekerjaan sampingan yaitu menjual anyaman tikar (kloso) keliling. Ada beberapa daerah yang biasanya menjadi tempat berjualan justru ditutup, sehingga terjadi penurunan omset penjualan sekitar 10 persen. Bantuan yang diterima tersebut, dirasakan cukup membantu meringankan beban ekonomi rumah tangga, tetapi harapan dari responden agar bantuan lebih diperbanyak, karena pengeluaran rumah tangga akibat harga bahan makanan dirasakan mengalami kenaikan, sedangkan penghasilan mengalami peurunan.

Upaya yang dilakukan responden agar usaha pertaniannya tidak memburuk dengan memberikan pertisida untuk ulat tanaman, sementara untuk hama tikus memberikan racun tikus disekeliling sawah. Upaya yang dilakukan agar ekonomi keluarga tidak memburuk adalah dengan tetap mengupayakan hasil pertanian yang lebih baik, baik dari sisi pemberantasan hama, pemilihan bibit yang baik, sampai dengan irigasi.

\section{Responden Nelayan}

Lokasi penelitian untuk responden nelayan di Jawa Timur, dipilih secara purposive di daerah Kabupaten Bangkalan. Produksi penangkapan perikanan laut Bangkalan, termasuk tertinggi setelah Lamongan, Sumenep, dan Banyuwangi, sebanyak 24.449 ton (BPS, 2017), dengan jumlah rumah tangga perikanan tangkap sebanyak 3212 rumah tangga. Satu-satunya pelabuhan perikanan di Kabupaten Bangkalan terdapat di Desa Banyu Sangkah Tanjung Bumi. Responden yang terpilih berasal dari wilayah Banyu sangkah Tanjung Bumi dan Arosbaya.

Responden pertama berasal dari Desa Banyu Sangka, Kecamatan Tanjung Bumi, seorang perempuan berusia 32 tahun. Responden merupakan ibu rumah tangga, lulusan $\mathrm{SD}$, dan istri dari nelayan, dengan jumlah anggota keluarga dalam rumah tangga tersebut sebanyak 5 orang. Anggota keluarga rumah tangga tersebut belum pernh menerima kredit usaha dari pihak manapun sebelumnya. Menurutnya COVID-19 merupakan penyakit dengan gejala demam, sesak nafas dan bersin-bersin. Reaksi masyarakat di sekitar kurang perduli, umumnya mereka bersikap biasa saja, dan cenderung tidak percaya. Perasaan sudah mulai khawatir ketika di luar rumah, baik kesehatan diri sendiri maupun kesehatan keluarga.
Responden kedua juga berasal dari Desa Banyu Sangka, Kecamatan Tanjung Bumi. Seorang perempuan berusia 60 tahun, yang tinggal berdua dengan suaminya. Responden merupakan ibu rumah tangga, lulusan SD. Seluruh anggota keluarga rumah tangga tersebut belum pernah menerima kredit usaha dari pihak manapun sebelumnya. Menurutnya COVID-19 penyakit yang tidak terlihat dengan mata, mudah menular tanpa mengenal usia dan juga menular. Reaksi masyarakat menurut responden terlalu berlebihan, terutama sikap terhadap orang yang sudah sembuh, tapi masyarakat masih tetap mengucilkannya.

Responden ketiga, berasal dari Lebak Arosbaya, seorang pria berumur 24 tahun, lulusan SMP, dan merupakan anak dalam rumah tangga tersebut. Anggota keluarga dalam rumah tersebut sebanyak 5 orang. Responden bukan pemilik kapal, jadi hanya ikut berlayar dengan hasil yang dibagi sesuai jumlah anggota. Sebelumnya anggota keluarga rumah tangga tersebut pernah menerima kredit usaha dari pegadaian. Menurut responden, COVID-19 merupakan penyakit yang menular yang meresahkan dan menyusahkan orang lain. Perasaan sudah mulai kuatir ketika di luar rumah, meskipun menurutnya masyarakat kurang perduli, karena belum pernah melihat gejala dan belum melihat bukti nyata, namun saat berpergian tetap mengikuti protokol yang di tetapkan.

\section{Informasi Awal}

Responden pertama menyatakan bahwa informasi awal yang diberikan oleh pihak desa, mengenai bantuan yang akan terima sudah sangat jelas, demikian pula dengan proses dan persyaratan yang harus dipenuhi cukup mudah. Menurut responden, para penerima bantuan di wilayah tersebut juga telah tepat sasaran. Responden kedua menyatakan bahwa informasi awal yang diberikan oleh pihak desa, mengenai bantuan yang akan terima juga sudah sangat jelas, adan tidak ada yang perlu diperbaiki. Proses dan persyaratan yang harus dipenuhi juga sangat mudah, serta para penerima bantuan di wilayah tersebut juga telah tepat sasaran. Responden ketiga menyatakan bahwa informasi awal yang diberikan oleh pihak desa, mengenai bantuan yang akan terima cukup jelas, demikian pula dengan proses dan persyaratan yang harus dipenuhi cukup mudah. Menurut responden, para penerima bantuan tersebut di wilayah tersebut juga masih belum tepat sasaran, karena masih banyak nelayan yang tidak menerima bantuan tersebut. Harapannya agar dalam prosesnya lebih teliti agar semua nelayan mendapatkan bantuan, terlebih untuk nelayan yang kurang mampu.

\section{Proses Pelaksanaan}

Bantuan yang diterima responden pertama, adalah Program Keluarga Harapan (PKH) sejak Desember 2018. Informasi pertama didapat dari Kepala Desa, dengan persyaratan cukup menggunakan fotocopy KTP dan KK. Tiap bulan menerima uang tunai $\mathrm{Rp} 500$ ribu dan juga memperoleh kartu sembako sejak Desember 2018. Paket sembako yang diperoleh berupa beras $10 \mathrm{~kg}$ atau $15 \mathrm{~kg}$, minyak 2 liter, kadang berupa buah atau daging ayam. Jika dihitung berdasarkan harga pasar, paket sembako tersebut bernilai sekitar Rp 170 ribu.

Bantuan yang diterima responden kedua, adalah Program Keluarga Harapan (PKH) sejak September 2018. Informasi pertama didapat dari Kepala Dusun, dengan 
persyaratan cukup menggunakan fotocopy KTP dan KK. Proses memperoleh bantuan, dengan mengumpulkan data ke balai desa kemudian langsung menerima bantuan uang tunai sebesar Rp 500 ribu. Informasi yang diperoleh bahwa bantuan tersebut sampai tahun 2025. Bantuan yang diterima lainnya adalah BLT, sebesar Rp 600 ribu, dan sampai wawancara dilakukan responden (september), telah menerima sebanyak tiga kali. Bantuan lain yang diperoleh adalah voucher beras, sejak September 2020. Isi sembako yang diberikan adalah beras $10 \mathrm{~kg}$, minyak 2 liter, telur 2 $\mathrm{kg}$, gula $1 \mathrm{~kg}$ kadang beras $10 \mathrm{~kg}$, buah $1 \mathrm{~kg}$, telur $1 \mathrm{~kg}$, dan daging ayam seperempat kilo, atau kalau diuangkan seharga Rp 220 ribu.

Bantuan yang diterima responden ketiga adalah Kartu Sembako. Informasi bantuan tersebut diperoleh dari warga setempat dan wakil kepala desa. Proses selanjutnya, warga disuruh ke balai desa langsung dengan membawa kupon yg diberikan oleh wakil kepala desa.

\section{Dampak}

Pendapatan bulanan responden pertama berada pada kisaran di bawah Rp 1,8 juta. Penghasilan rata-rata untuk sekali tangkap periode sebelum wabah sekitar Rp 50 ribu perhari, sedangkan saat ini penghasilan rata-rata untuk sekali tangkap hanya sekitar Rp 20 ribu perhari, tetapi penurunan tersebut terjadi bukan karena COVID-19 tetapi lebih karena faktor cuaca yang kurang mendukung. Terkait pertanyaan apakah bantuan yang telah diberikan membantu meringankan beban ekonomi kelurga, responden menjawab tidak membantu. Menurut responden, lebih baik jika ada tambahan besaran bantuan agar cukup memenuhi kebutuhan rumah tangga, dan menurut responden hanya pemerintah yang mampu memberikan bantuan tersebut. Upaya yang dilakukan untuk menopang kebutuhan ekonomi rumah tangga adalah dengan berjualan kecil-kecilan di rumah, meskipun hasilnya saat ini masih sedikit.

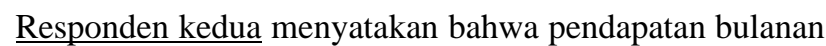
berkisar Rp 600 ribu, sehingga masuk pada kategori di bawah Rp 1,8 juta. Menurut responden pendapatan per hari saat ini sebesar Rp 50 ribu, sedangkan sebelum pandemi sekitar Rp 75 ribu per hari. Menurut responden, penurunan pendapatan terjadi karena orang mulai jarang belanja ikan di pasar, sehingga ikan yang dijual tidak laku. Pengeluaran rumah tangga disesuakan juga dengan penurunan pendapatan tersebut. Menurut responden, bantuan yang diterima tersebut, membantu meringankan beban ekonomi keluarga, dan responden mengharapkan bantuan tersebut terus berjalan dan menilai nominalnya yang diterimanya masih kurang banyak. Upaya yang agar usaha perikanan tidak memburuk dengan pindah pasar dan cari pelanggan, serta dengan berjualan kecil-kecilan di rumah.

Responden ketiga, memiliki pendapatan rumah tangga berkisar dibawah Rp 1,8 juta. Penghasilan saat ini juga mengalami penurunan dari sebelum wabah, dari sekitar Rp 100 ribu pertangkap menjadi Rp 30 ribu pertangkap. Selain karena faktor cuaca, saat wawancara dilakukan penjualan juga kurang laku karena pembeli sering menawar dengan harga lebih rendah, dan ikan yang dijual sering tidak habis. Menurut responden, bantuan berupa uang tunai jauh lebih efektif untuk nelayan daripada kartu sembako yang diterimanya. Harusnya pemerintah mampu melakukan pemberian bantuan tersebut, dan juga partisipasi orang yang mampu di sekitar wilayah tersebut. Strategi yang dilakukan agar usaha tidak memburuk dengan menurunkan harga ikan tangkapannya, dan mungkin dengan melakukan pekerjaan lain.

\section{Responden Usaha Mikro}

Lokasi penelitian untuk responden Usaha Mikro di Jawa Timur, dipilih secara purposive di daerah Kabupaten Gresik. Kabupaten Gresik merupakan daerah yang mengalami perkembangan cukup pesat di sektor industri, mulai dari industri rumahan hingga industri yang berskala besar. Beberapa industri juga berkembang di setiap Kecamatan yang ada di Kabupaten Gresik. Menurut data BPS Jawa Timur tercatat 225.242 UMKM berada di Kabupaten Gresik. Untuk tahap awal bantuan terdampak COVID-19, Dinas Koperasi Usaha Mikro dan Perindustrian Perdagangan Gresik, Agustus 2020 telah mengusulkan kepada KEMENKOP sebanyak 1.014 UMKM daerah tersebut untuk mendapatkan stimulus bantuan (radargresik.jawapos.com). Responden yang terpilih ketiganya berasal dari wilayah Kecamatan Kebomas.

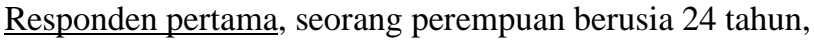
lulusan S1, merupakan pemilik usaha souvenir, flower store. Usaha tersebut mulai ditekuni sejak umur 17 tahun, yang awalnya hobi berjualan hingga menjadi wirausaha muda. Modal usahanya dari model sendiri, ada tambahan kredit usaha berupa KUR yang baru berjalan 4 bulan terakhir. Saat wawancara memiliki 3 karyawan, yaitu 2 orang bagian merangkai bunga dan 1 orang kurir. Menurutnya wabah COVID-19 yang menyerang Indonesia pada saat awal tahun akan berdampak tidak hanya pada usaha besar, namun juga usaha kecil seperti UMKM akan terkena imbasnya. Perasaan sudah mulai kuatir ketika di luar rumah, meskipun menurutnya masyarakat sudah cukup proposional menyikapi dan mulai mengerti hidup di era new normal.

Responden kedua, seorang pria berumur 35 tahun, lulusan SMA, dengan 6 anggota rumah tangganya. Responden saat wawancara dilakukan memiliki usaha bengkel sepeda motor. Sebelumya belum pernah menerima kredit usaha dari pihak manapun. Menurutnya masyarakat sekitar dapat menyikapi COVID-19 secara proposional, mengerti protokol kesehatan dan cara agar menjaga daya tahan tubuh. Banyak masyarakat yang suka olahraga, berjemur dan menggunakan masker semenjak adanya COVID-19.

Responden ketiga, seorang ibu rumah tangga satu anak, berumur 23 tahun, lulusan MTs. Pernah menerima kredit usaha dari perorangan dengan membayar bunga tertentu. Sebelum membuka warung kopi adalah pedagang makanan untuk anak sekolah SD, karena sistem daring maka beralih membuat warung kopi dan jajanan anakanak. Menurutnya masyarakat di sana sudah terbiasa dengan adanya COVID-19, sehingga menjadi hal yang biasa, dampaknya banyak masyarakat yang tidak memakai masker pada saat membeli kopi. Namun untungnya pemerintah selalu melakukan operasi setiap malam untuk cek masker, dengan begitu masyarakat mau tidak mau tetap menggunakan masker. 


\section{Informasi Awal}

Responden pertama menyatakan bahwa informasi awal tidak melibatkan perangkat desa karena diperoleh dari internet dan website. Informasi yang diterima responden juga jelas terdapat di internet dan website BRI. Proses yang kemudian dilalui untuk memperoleh bantuan tersebut juga cukup mudah, dan persyaratan yang diharuskan penuhi juga cukup mudah yaitu KTP, KK, dan surat izin usaha.

Responden kedua menyatakan bahwa informasi awal yang diberikan oleh pihak desa mengenai bantuan yang akan diterima kurang jelas, karena pemberitahuannya sangat mendadak, menurut responden seharusnya ada pemberitahuan sebelumnya agar ada persiapan bagi para calon penerima BLT tersebut. Meskupun demikian menurut responden persyaratan yang diperlukan sngat mudah yaitu KTP, KK, dan Materai 2 lembar. Menurut responden para penerima bantuan tersebut di wilayah tersebut juga tepat sasaran.

Responden ketiga menyampaikan bahwa informasi awal yang diberikan oleh pihak desa mengenai bantuan yang akan diterima kurang jelas, seharusnya informasi adanya bantuan BLT tersebut tidak mendadak dan masyarakat diberi informasi sampai kapan bantuan BLT tersebut berakhir. Persyaratan yang harus dipenuhi sangat mudah yaitu KTP, KK, dan materai 2 lembar, sedangkan yang bantuan listrik bersubsidi juga sangat mudah melalui website.

\section{Proses Pelaksanaan}

Bantuan yang diterima responden pertama, adalah Kredit Usaha Rakyat. Informasi pertama didapat dari internet, kemudian mengajukan KUR di Kantor Cabang Gresik, dan sudah menerima sejak bulan Maret 2020. Persyaratan yang harus dipenuhi adalah (1) Memiliki usaha yang produktif dan layak (2) Tidak mempunyai kredit di bank lain, (3) Mengisi formulir pengajuan KUR secara lengkap dan akurat serta (4) menyertakan dokumen berupa KTP, KK, dan surat izin usaha.

Bantuan yang diterima responden kedua adalah Bantuan Langsung Tunai. Informasi bantuan tersebut diperoleh dari desa, melalui perangkat desa. Proses memperoleh bantuan tersebut dimulai pada bulan Mei dengan mengajukan persyaratan, berupa KTP, KK, dan Materai sebanyak 2 lembar. BLT tesebut berupa uang tunai Rp. 600.000, sampai dengan wawancara bulan Agustus, sudah cair 3 bulan berturut-turut yaitu pada bulan Mei, Juni, dan Juli.

Responden ketiga memperoleh BLT dan diskon pelanggan listrik 900V subsidi. Informasi pertama diperoleh dari Kepala Desa, dengan persyaratan berupa KTP, KK, dan Materai sebanyak 2 lembar. Pengajuan persyaratan untuk mendapatkan BLT pada bulan Mei, kemudian cair pada bulan Mei, Juni, Juli dan bulan Agustus, masing-masing sebesar Rp. 600.000. Sampai kapan bantuan tersebut akan diperoleh, responden menyatakan tidak memperoleh informasi, yang penting bagi responden adalah sudah memperoleh bantuan tersebut. Sedangkan untuk bantuan kedua, informasi diperoleh dari Ketua RT setempat. Proses memperoleh bantuan tersebut, dengan membuka website www.pln.co.id, masuk menu pelanggan, dan menuju pilihan stimulus COVID-19 lalu memasukan nomor meteran, selanjutnya token gratis akan ditampilkan di layar, dan yang terakhir memasukan token gratis tersebut ke meteran. Persyaratannya adalah yang menggunakan listrik 900v subsidi. Bentuk bantuan yang diterima adalah listrik gratis. Informasi yang diterima responden, program tersebut hanya sampai Desember 2020.

\section{Dampak}

Pendapatan bulanan responden pertama saat wawancara dilakukan berada pada kisaran diatas 7,2 juta rupiah. Menurutnya pengaruh wabah COVID-19 terhadap usahanya hanya dirasakan pada bulan pertama PSBB, untuk bulan-bulan berikutnya imbasnya tidak terlalu diraskan. hal tersebut bisa terjadi karena responden melakukan upaya memperbarui produk produk yang dijual dengan ide-ide jaman sekarang bukan hanya menjual bucket bunga saja. Omset harian, mingguan, dan bulanan responden dari usaha tersebut juga masih tetap meningkat, dari omset harian rata-rata sekitar Rp 1,25 juta sebelum wabah, saat wawancara dilakukan masih berada pada $\mathrm{Rp}$ 1,3 juta perhari. Adanya bantuan KUR membantu meringankan perkembangan usaha. Harapan responden adalah selain adanya insentif melalui KUR, juga terdapat insentif dari sisi pengeluaran, misalnya pengurangan biaya listrik dan pajak penghasilan.

Strategi yang dilakukan responden untuk mempertahankan usaha bunga tersebut adalah dengan adanya pengolahan bunga dengan berbagai macam varian seperti Snack Bucket, Money Bucket, Dried Flowers in Frame, Bucket Graduatiot. Pemasaran dilakukan dengan melalui pembuatan blog, Instagram, Endorse serta gratis masker cantik di masa pandemi COVID-19, untuk setiap pembelian tertentu. Adanya ide-ide dan strategi baru dan juga promosi melalui instagram, endorse, ataupun memperbanyak variasi produk diyakini akan memepertahankan bahkan meningkatkan perekonomian keluarga.

Responden kedua menyatakan bahwa dengan adanya pandemi sangat memukul kondisi usahanya. Pada masa sebelum pandemi, pendapatan bulanan pada kisaran Rp 3 jutaan, untuk saat ini berkurang sekitar 50 persen. Bantuan yang diterima saat wawancara dilakukan menurutnya sangat membantu meringankan beban ekonomi keluarga. Harapannya program tersebut dapat diperpanjang pelaksanaannya. Menurutnya pihak pemerintah yang dapat melakukan perbaikan untuk meringankan beban tersebut. Strategi usaha yang dilakukan agar tidak memburuk, dengan menambah peralatan ataupun perlengkapan usaha, contoh yang pada awalnya hanya melayani tambal ban saja, sekarang dengan menjual ban dan ada tambahan peralatan pengganti ban, agar lebih meminimalkan waktu. Selain itu juga menjual peralatan dan asesoris untuk otomotif. Jika pelanggan semakin bertambah, maka beban ekonomi keluarga juga semakin baik.

Responden ketiga menyatakan bahwa adanya pandemi menyebabkan pendapatan usahanya mengalami penurunan. Jika sebelum masa pandemi, omset harian mencapai Rp 100 ribuan, maka saat wawancara dilakukan hanya sekitar Rp 70 ribu perhari, akibatnya pendapatan perbulan juga mengalami penurunan, meskipun dari sisi pengeluaran rumah tangga, menurutnya tidak mengalami kenaikan. Bantuan yang diterima berupa BLT dan 
pengurangan biaya listrik, menurutnya cukup membantu meringankan beban rumah tangga, dan menurutnya hanya pemerintah yang mampu memberikan bantuan untuk meringankan beban tersebut. Upaya yang dilakukan agar usahanya tidak memburuk dengan menambah menu warung kopi dan memasang WiFi. Adanya warung kopi dan WiFi, diharapkan banyak yang datang membeli minuman dan dapat memanfaatkan WiFi. Upaya lain dengan tetap mempertahankan berjualan jajanan anak sekolah agar tetap ada yang membeli.

\section{Pembahasan}

State of art penelitian mengkaji masalah yang saat wawancara dilakukan sedang dihadapi dan sedang berlangsung di Indonesia yaitu pandemi COVID-19. Riset terdahulu memberikan dasar kajian dan evaluasi pelaksanaan bantuan tunai di Indonesia, dan respon dari kelompok masyarakat berpenghasilan rendah, yaitu petani dan nelayan miskin, serta para pelaku usaha mikro. Hasil riset diharapkan menjadi langkah awal untuk penelitian yang lebih luas yaitu evaluasi bantuan program secara nasional.

Hasil wawancara dengan keseluruhan responden menunjukkan secara umum responden memahami adanya wabah COVID-19 sebagai penyakit menular yang cukup meresahkan. Paling tidak tercermin dari penyataan bahwa sebagian besar merasa khawatir terhadap kesehatan mereka ketika keluar rumah. Perilaku masyarakat di sekitar dirasakan masih kurang peduli, terutama dalam penggunaan masker, meskipun sebagian menilai sudah tepat atau proposional, yang ditandai dengan mulai sadar lebih menjaga jarak dengan yang lain. Upaya pemberian rasa aman terhadap aktivitas keseharian di luar rumah dengan terus memberikan sosialisasi pelaksanaan protokol kesehatan terutama di tempat umum, tempat kerja perkantoran, bahkan sampai ke ladang pertanian dan perikanan. Upaya peningkatan kesadaran harus disertai pemantauan penggunaan masker dan alat bantu pencegahan lainya untuk mencegah penularan. Edukasi terhadap masyarakat terhadap pasien COVID, dan pasien yang sudah sembuh juga harus dilakukan, agar tidak dikucilkan sehingga memperburuk kondisi ekonomi yang bersangkutan.

Hasil wawancara menunjukkan bahwa beberapa responden memperoleh bantuan sosial pemerintah pada saat pandemi, sedangkan sebagian sudah memperoleh bantuan sosial sebelum pandemi. Selain itu terdapat responden yang telah memperoleh pembiayaan produktif KUR. Variasi bantuan yang di terima saat pandemi adalah diskon tarif PLN. Sedangkan bantuan sosial seperti PKH, dan kartu sembako ada yang baru menerima saat pandemi, tetapi ada yang sudah memperoleh pada tahun sebelumnya, yaitu tahun 2018 dan 2019. Responden yang telah memanfaatkan skema KUR, merupakan kredit bersubsidi bunga dari pemerintah, dengan tujuan untuk peningkatan usaha produktif, sedangkan responden yang memperoleh bantuan sembako, PKH dan subsidi listrik, dimanfaatkan untuk menopang pendapatan rumah tangga yang terdampak pandemi.

Penilaian terhadap informasi awal yang diberikan oleh pihak desa, sudah sangat jelas, demikian pula dengan proses dan persyaratan yang harus dipenuhi cukup mudah. Mengenai ketepatan sasaran, menurut pendapat beberapa responden masih belum tepat sasaran, karena masih banyak tetangga warga responden yang tidak menerima bantuan tersebut, yang menurut beberapa responden layak menerima. Hal tersebut menunjukkan bahwa perluasan cakupan dan perbaikan data penerima baru harus mendapat perhatian dari pemerintah, tentunya tetap memperhatikan usulan dari pengurus dan perangkat desa setempat untuk verifikasinya.

Proses memperoleh informasi untuk KUR tidak berasal dari perangkat desa, karena diakses langsung responden dari internet, yang kemudian ditindaklanjuti ke kantor bank yang bersangkutan, harusnya menjadikan masukan bahwa keseluruhan program termasuk nantinya stimulus KUR atau bahkan bantuan suku bunga dari lembaga keuangan lainnya harus juga diketahui oleh para pengurus atau perangkat desa, yang kemudian akan dengan lebih mudah dan cepat sampai kepada masyarakat setempat. Pengetahuan dan pemberian informasi terkini tentang bantuan sosial dan bantuan tanggap COVID-19, harus senantiasa diberikan oleh pejabat pemerintah yang berwenang kepada kepada perangkat desa, yang selanjutnya harus juga diinformasikan kepada masyarakat setempat.

Hasil wawancara dengan beberapa responden menunjukkan dampak COVID-19 terhadap pendapatan rumah tangga para responden menyatakan tidak atau belum berpengaruh. Responden petani merasakan penurunan pendapatan rumah tangga, justru diakibatkan karena penurunan hasil panen, yang berasal dari serangan hama tikus, ulat dan burung yang sedang menyerang tanaman padi beberapa periode panen terakhir. Responden nelayan memiliki jawaban bahwa terjadi penurunan pendapatan bulanan, selain faktor cuaca yang kurang mendukung, harga ikan yang cenderung turun terjadi karena penurunan pembeli ikan di pasar.

Dampak pandemi untuk responden UMKM berbeda-beda, salah satu responden menyatakan tidak mengalami penurunan omset, bahkan mengalami kenaikan omset, tetapi kondisi sebaliknya dialami oleh responden lainnya, yang menyatakan bahwa kondisi saat wawancara dilakukan sangat memukul kondisi penghasilan keluarganya, dengan penurunan omset bulanan sekitar 50 persen. Hal tersebut menjadi indikasi awal bahwa sektor usaha mikro lebih rentan terkena dampak ekonomi pandemi, kemudian nelayan atau sektor perikanan akan terkena dampak tidak langsung melalui berkurangnya pembeli di pasar, sedangkan petani atau sektor pertanian lebih tidak rentan terkena pandemi, tetapi tetap menghadapi masalah dan resiko yang juga berdampak besar merugikan hasil pertanian, seperti hama tikus.

Upaya yang dilakukan responden agar usaha pertaniannya tidak memburuk, untuk usaha pertanian dengan menjaga tanaman dari serangan hama, dan tetap menjaga proses pembibitan, penanaman dan irigasinya. Untuk responden usaha mikro melakukan strategi perluasan dan variasi produk, dan menghasilkan keuntungan, sedangkan responden lainnya juga melakukan variasi usaha sesuai dengan kapasitas usahanya, tetapi belum mampu menghasilkan keuntungan yang setara dengan kondisi 
sebelum pandemi. Bantuan yang telah diberikan masih dirasakan belum cukup membantu, dengan harapan ada tambahan bantuan dari pemerintah, dan mungkin juga pihak masyarakat yang lain, agar dapat memenuhi kebutuhan rumah tangga khususnya masyarakat yang benar benar membutuhkan dan terdampak pandemi. Adanya bantuan berupa cash transfer tersebut, sesuai dengan teori memungkinkan rumah tangga mempertahankan atau meningkatkan belanja agar tingkat kesejahteraan rumah tangga bertambah, sedangkan pemberian bentuk barang. Pemberian kompensasi dalam bentuk dalam bentuk bahan makanan pokok, bumbu dapur, dan buah-buahan dapat mempertahankan tingkat konsumsi rumah tangga penrima bantuan.

\section{Simpulan}

Simpulan dari penelitian sebagai berikut:

Penilaian terhadap informasi awal, sebagian besar menilai sudah cukup jelas, proses memperoleh bantuan juga mudah, demikian pula persyaratan yang harus dipenuhi juga mudah. Hal tersebut dapat berjalan dengan baik, ditunjang partisipasi aktif dari para perangkat desa. Meskipun demikian responden menyatakan masih perlu perluasan sasaran penerima, sehingga lebih tepat sasaran. Pelaksanaan bantuan tanggap pandemi telah berjalan, seiring dengan bantuan sosial yang telah berjalan sebelumnya. Sebagian responden memperoleh bantuan sosial sebelum pandemi, dan sebagian lainnya, memperoleh variasi bantuan pada saat pandemi. Sebagian besar memanfaatkan bantuan untuk menopang pendapatan rumah tangga, baik yang terdampak langsung maupun tidak langsung. Dampak COVID-19 terhadap pendapatan kelompok usaha di masyarakat tergantung dari jenis usaha, skala usaha, kemampuan strategi pemilik usaha. Indikasi awal bahwa sektor usaha mikro lebih rentan terkena dampak pandemi, nelayan sebagian besar terkena dampak tidak langsung, sedangkan petani lebih tahan pandemi, tetapi tetap menghadapi masalah dan resiko gagal panen.

Implikasi penelitian: Pemerintah dapat memetakan pengaruh COVID-19 terhadap pendapatan usaha petani, nelayan dan pelaku usaha mikro, berdasarkan jenis, skala usaha, kemampuan serta strategi pemilik usaha, sehingga diperoleh formula pemberian bantuan yang lebih tepat sesuai kebutuhan masing-masing pelaku usaha.Terkait dengan keterbatasan penelitian, yang dilakukan pada saat bantuan tanggap pandemi sedang dan belum berjalan untuk jenis bantuan tertentu, maka untuk peneliti berikutnya dapat melakukan kebaruan dengan melakukan penelitian terkini selanjutnya.

\section{Ucapan Terimakasih}

Terima kasih kepada pihak LPPM Universitas Trunojoyo Madura yang memberikan bantuan dana dalam rangka penelitian dan penerbitan artikel ini.

\section{Referensi}

BPS. (2019). Keadaan Angkatan Kerja di Indonesia Agustus 2019.
Buana, D. R. (2020). Analisis Perilaku Masyarakat Indonesia dalam Menghadapi Pandemi Virus Corona (COVID-19) dan Kiat Menjaga Kesejahteraan Jiwa. Salam: Jurnal Sosial dan Budaya Syar-i, 7(3).

Budianto, H. (2015). Respon Anggota Kelompok Tani terhadap Program Pengembangan Usaha Agribisnis Perdesaan (Puap) di Kecamatan Kebun Tebu Kabupaten Lampung Barat.

Creswell, J. W., \& Creswell, J. D. (2017). Research design: Qualitative, quantitative, and mixed methods approaches. Sage publications.

Djalante, R., Lassa, J., Setiamarga, D., Mahfud, C., Sudjatma, A., Indrawan, M., ... \& Gunawan, L. A. (2020). Review and analysis of current responses to COVID-19 in Indonesia: Period of January to March 2020. Progress in Disaster Science, 100091.

Fadli, A. (2017). Respon Nelayan Terhadap Peraturan Menteri Kelautan Dan Perikanan Nomor 1 Tahun 2015 (Studi Deskriptif di Pantai Payangan Desa Sumberejo Kabupaten Jember).

Fakhruddin, B., Blanchard, K., \& Ragupathy, D. (2020). Are we there yet? The transition from response to recovery for the COVID-19 pandemic. Progress in Disaster Science, 100102.

Hidayat, E. (2018). The Business Actors' Response to The Liability of Determining Halal Certification for Ayam Penyet Surabaya and Super Geprek Sleman Yogyakarta.

Joharudin, A., Septiadi, M. A., Maharani, S., Aisi, T. D., \& Nurwahyuningsih, N. (2020). Panic Syndrom COVID-19: Penekanan Terhadap Kebijakan Yang Diberikan. Jurnal Perspektif, 4(1), 44-53.

Jonyanis, J., \& Wahyuni, S. (2015). Respon Nelayan terhadap Program Bantuan Pemerintah Desa Tanjung Lumba-lumba Kecamatan Kubu Kabupaten Rokan Hilir (Doctoral dissertation, Riau University).

Kemenkeu (2020). Ini Insentif Bantuan Sosial Pemerintah Untuk Masyarakat, SP -25 /KLI/2020. https://www.kemenkeu.go.id/publikasi/siaranpers/siaran-pers-ini-insentif-bantuan-sosialpemerintah-untuk-masyarakat/

Kemenkeu (2020b). Perkembangan Ekonomi dan Refocusing Anggaran untuk Penanganan COVID-19 di Indonesia, SP - 31 /KLI/2020. https://www.kemenkeu.go.id/publikasi/siaranpers/siaran-pers-perkembangan-ekonomi-danrefocusing-anggaran-untuk-penangananCOVID-19-di-indonesia/

Kurniawati, L. (2017). Dampak Penurunan Subsidi Bahan Bakar Minyak: Analisis Sistem Neraca Sosial Ekonomi Indonesia. Info Artha, 1(2), 91-110.

Khomaini, A. A. (2020). Dampak Program Bantuan Tunai (Cash Transfer) terhadap Kesejahteraan Subyektif di Indonesia. Indonesian Treasury 
Review: Jurnal Perbendaharaan, Keuangan Negara dan Kebijakan Publik, 5(1), 1-16.

Mankiw, N. G. (2013). Macroeconomics. Eight Edition. New York: Worth Publisher

Mufida, A. (2020). Polemik Pemberian Bantuan Sosial Di Tengah Pandemic COVID 19. 'Adalah, 4(1).

Neuman, W. L. (2017). Metodologi Penelitian Sosial: Pendekatan Kualitatif dan Kualitatif (Edisi Tujuh). Jakarta: PT. Indeks.

Pakpahan, A. K. (2020). COVID-19 Dan Implikasi Bagi Usaha Mikro, Kecil, Dan Menengah. Jurnal Ilmiah Hubungan Internasional, 59-64.

Purwono, R., Nugroho, R. Y. Y., \& Mubin, M. K. (2019). Response on New Credit Program In Indonesia: An Asymmetric Information Perspective. The Journal of Asian Finance, Economics and Business (JAFEB), 6(2), 33-44.

Putra, S., \& Haryati, Y. (2018). Kajian Produktivitas dan Respon Petani terhadap Padi Varietas Unggul Baru di Kecamatan Parungkuda dan Cicantayan Kabupaten Sukabumi.
Rosfadhila, M., Toyamah, N., Sulaksono, B., Devina, S., Sodo, R. J., \& Syukri, M. (2011). Kajian Cepat Pelaksanaan Program Bantuan Langsung Tunai (BLT) 2008 dan Evaluasi Penerima Program BLT 2005 di Indonesia. SMERU Research Institute, 1107.

Siregar, H. (2020). Perbankan Nasional Pada Era Pandemi COVID-19. Webinar Perbanas Institut, $20 \mathrm{Mei}$ 2020. https://perbanas.id/2020/05/22/webinarperbankan-perbankan-di-era-pandemi-COVID19/

World Bank (2020). Poverty and Distributional Impacts of COVID-19: Potential Channels of Impact and Mitigating Policies.

Woldometer. (2020, September 30). Total cases corona virus.https://www.worldometers.info/coronaviru s/worldwide-graphs/\#total-cases

World Health Organization (2020). Coronavirus disease 2019 (COVID-19): situation report, 72. 